\title{
IMPLEMENTASI PENDEKATAN SAINTIFIK (METODE 5M) DALAM KURIKULUM 2013 TERHADAP PENINGKATAN PEMAHAMAN MATAKULIAH TEORI BILANGAN PADA MAHASISWA SEMESTER 3 PROGRAM STUDI PENDIDIKAN MATEMATIKA STKIP BIMA
}

\author{
Edi Mulyadin \\ Program Studi Pendidikan Matematika, STKIP Bima \\ "Email korespondensi: edi.mulyadin_mat@stkipbima.ac.id
}

\begin{abstract}
ABSTRAK
Penelitian ini bertujuan untuk mendeskripsikan bagaimanakah Peningkatan Pemahaman Konsep Teori Bilangan dengan Pendekatan Saintifik (Metode 5M) Dalam Kurikulum 2013 Pada mahasiswa Semester 3 Program Studi Pendidikan Matematika STKIP Bima. Jenis penelitian ini menggunakan penelitiaan tindakan kelas (PTK) karena peneliti merumuskan rencana tindakan dan ikut melaksanakan rencana dalam penelitian ini, peneliti akan berpartisipasi aktif dan ikut melaksanakan rencana dalam proses penelitian ini. Berdasarkan hasil penelitian Pendekatan Saintifik mampu meningkatkan hasil belajar mahasiswa semester III A melalui tahapan yaitu mengamati, menanya, menyajikan, menalar, dan mencoba. Ketuntasan belajar pada siklus I sebesar 57,69\% sedangkan pada siklus II sebesar $100 \%$.
\end{abstract}

Kata Kunci : Pendekatan Saintifik (metode 5M), Hasil Belajar.

\begin{abstract}
This study aims to describe how the Increased Understanding of Number Theory Concepts with the Scientific Approach (5M Method) in the 2013 Curriculum in Semester 3 students of the STKIP Bima Mathematics Education Study Program. . This type of research uses classroom action research (CAR) because researchers formulate action plans and participate in implementing plans in this study, researchers will actively participate and participate in implementing plans in this research process. Based on the results of the Scientific Approach is able to improve student learning outcomes semester III A through the stages of observing, asking, presenting, reasoning, and trying. Completion of learning in the first cycle of $57.69 \%$ while in the second cycle of $100 \%$.
\end{abstract}

Keywords: Scientific Approach (5M method), Learning Outcomes.

\section{PENDAHULUAN}

Menurut Mulyadin (2013) Pendidikan Budi Pekerti dimaknai sebagai usaha sadar melalui kegiatan bimbingan, pembiasaan, pengajaran dan latihan, serta keteladanan untuk menyiapkan peserta didik menjadi manusia seutuhnya yang berbudi pekerti luhur dalam 
segenap peranannya di masa yang akan datang, Pendidikan merupakan daya upaya untuk memajukan budi pekerti (karakter, kekuatan bathin), pikiran (intellect) dan jasmani seseorang selaras dengan alam dan masyarakatnya. Daya dan upaya yang termaktub dalam konsep tersebut harus diselaraskan dalam sebuah rancangan strategis yang kini disebut sebagai kurikulum. John Wiles (dalam Mulyadin, 2018) mengatakan bahwa kurikulum adalah jantungnya pendidikan.

Menurut Sriaryaningsyih (2019) beberapa masalah maupun kendala dalam pembelajaran matematika diantarannya yang sering ditemukan yaitu: (1) Aktivitas siswa dalam proses belajar mengajar yang terlihat sangat membosankan yang dikarenakan hampir setiap kali pertemuan masih menggunakan cara belajar yang sama, terutama dalam pembelajaran matematika. (2) Persepsi atau tanggapan siswa tentang cara belajar yang diajarkan oleh guru. Dalam pembelajaran matematika sebagian besar siswa mengatakan malas dengan belajar matematika dan bahkan menyatakan tidak suka dan takut terhadap guru-guru matematika. dan (3) Hasil belajar siswa pada mata pelajaran matematika masih tidak maksimal, ini tidak terlepas dari aktivitas belajar mengajar dan persepsi siswa terhadap matematika. Ini diperlukan peran seorang guru untuk menciptakan pembelajaran yang membuat siswa tidak merasa bosan ketika belajar.

Berdasarkan pengamatan awal mahasiswa yang mengikuti mata kuliah Teori Bilangan diperoleh informasi bahwa pemahaman konsep dan membuktikan dengan induksi matematika dianggap kegiatan yang sulit dan tidak menyenangkan. Mata kuliah Teori Bilangan merupakan salah mata kuliah Keahlian Bidang Studi Matematika yang bertujuan memperkuat landasan materi matematika terutama yang mempunyai hubungan dengan matematika sekolah, yaitu materi tentang bilangan, dan memperluas wawasan ke dalam kajian materi matematika terutama yang mempunyai hubungan dengan persamaan Aljabar.

Kong (2003) dalam penelitiannya menemukan tiga kesulitan mahasiswa dalam melakukan pembuktian dengan induksi matematika yaitu kesulitan konseptual, prosedural, dan teknis. Kesulitan konseptual lebih ke pemahaman dari metode pembuktian dengan induksi matematika, hubungan antara hipotesis induksi dan langkah induksi dan kebutuhan dari kasus basis. Kesulitan prosedural lebih kepada kesulitan ketika menemui kasus basis tidak dimulai 
dengan $\mathrm{n}=1$ dan diberikan pernyataan yang salah. Kesulitan teknis lebih kepada kesulitan dalam memanipulasi aljabar dan ketidaktepatan dalam mensubtitusikan dari variable. Selain tiga jenis kesulitan tersebut Kong juga menemukan bahwa kurangnya pengetahuan mahasiswa terhadap isi dari matematika terhadap topik tertentu sangat mempengarui kemampuan dalam melengkapi pembuktian dengan induksi matematika.

Taufik (2014) dalam penelitiannya menemukan letak kesulitan mahasiswa dalam pembuktian menggunakan induksi matematika yaitu: (a) Pada langkah membuat pernyataan, (b) Pada langka membuat hipotesis, (c) Pada langkah merumuskan bentuk $\mathrm{Pk}_{\mathrm{k}+1}$, dan (d) Pada langkah memanipulasi aljabar untuk menunjukkan kebenaran dari $\mathrm{P}_{k+1}$.Untuk itu, perlu menggunakan pendekatan yang dapat membantu dalam memecahkan masalah-masalah yang diidentifikasi di atas. Hal itu akan sejalan dengan konsep "5M" dalam Kurikulum 2013 yakni mengamati, menanya, menalar, mencoba, dan mengkomunikasikannya.

Kemendikbud (2013) menekankan bahwa langkah-langkah Kurikulum 2013 pada dimensi pedagogik modern dalam pembelajaran, yaitu menggunakan pendekatan ilmiah. Pendekatan ilmiah (scientific appoach) dalam pembelajaran sebagaimana dimaksud meliputi mengamati, menanya, mencoba, mengolah, menyajikan, menyimpulkan, dan mencipta. Untuk materi, atau situasi tertentu, sangat mungkin pendekatan ilmiah ini tidak selalu tepat diaplikasikan secara prosedural. Pada kondisi seperti ini, tentu saja proses pembelajaran harus tetap menerapkan nilai-nilai atau sifat-sifat ilmiah dan menghindari nilainilai atau sifat-sifat nonilmiah.

Pelaksanaan Kurikulum 2013 seperti yang sudah dikatakan di tersebut, dilaksanakan melalui Pendekatan Saintifik (Scientific). Pada pelaksanaannya, pendekatan ini menekankan pada lima aspek penting yang juga dikenal dengan istilah "5M", yaitu mengamati, menanya, mencoba, menalar dan komunikasi. Lima aspek ini harus benar-benar terlihat pada pelaksanaan pembelajaran di lapangan.

Langkah pertama adalah mengamati. Proses mengamati ini sangatlah penting, di mana Siswa menghadirkan angan menjadi nyata. Siswa tidak lagi mengkhayal dalam setiap pembelajaran, Siswa sudah melihat langsung proses percobaan yang dituntun guru sebelum mencoba. Langkah kedua adalah bertanya. 
Hal ini dilakukan guru dengan membuka pembelajaran dengan menimbulkan masalah.

Langkah selanjutnya adalah mencoba. Mencoba akan membuat Siswa sadar bahwa materi ajar sangat penting dalam kehidupan mereka sehari-hari, maka motivasi mereka seharusnya bukan lagi mengejar nilai. Siswa yang mencoba akan paham bahwa materi yang diajarkan guru berguna untuk mereka. Langkah berikutnya adalah menalar. Proses penalaran inilah yang kemudian membuat Siswa mencerna dengan baik, memilah baik-buruk, lalu mendapatkan kesimpulan.

Langkah terakhir adalah mengkomunikasikan. Siswa dituntut untuk mampu mengkomunikasikan permasalahan sehingga mampu memahami dan menjalankan materi ajar dengan benar dalam kehidupan sehari-hari. Kelima langkah tersebut harus terlihat dengan benar dalam Implementasi kurikulum 2013. Berkaitan dengan hal itu, maka melihat urgensinya aplikasi kurikulum 2013 dan hubungannya dengan peningkatan kualitas pendidikan untuk menekan "ancaman" dari luar, khususnya dalam pembelajaran bahasa Indonesia sebagai mata pelajaran wajib, maka dalam konteks ini, penelitian ini diarahkan pada Implementasi pendekatan saintifik tersebut dalam materi menulis. Keterampilan menulis merupakan urutan yang terakhir dalam belajar berbahasa. Keterampilan ini merupakan "muara" dari tiga keterampilan lainnya. Keterampilan ini juga cenderung menjadi "pangeran" dibanding tiga keterampilan lainnya karena alur berpikir seseorang akan terlihat dari tulisan yang diciptakannya.

Berdasarkan uraian diatas maka tujuan yang ingin dicapai dalam penelitian ini adalah untuk mendeskripsikan bagaimanakah Peningkatan Pemahaman Konsep Teori Bilangan dengan Pendekatan Saintifik (Metode 5M) dalam Kurikulum 2013 Pada mahasiswa Semester 3 Program Studi Pendidikan Matematika STKIP Bima.

\section{METODE PENELITIAN}

Jenis penelitian ini menggunakan penelitian tindakan kelas (PTK) karena peneliti merumuskan rencana tindakan dan ikut melaksanakan rencana dalam penelitian ini, peneliti akan berpartisipasi aktif dan ikut melaksanakan rencana dalam proses penelitian ini. Menurut Wibawa (2003) Penelitian tindakan kelas (PTK) merupakan suatu penelitian yang mengangkat 
masalah-masalah aktual yang dihadapi oleh guru di lapangan. Arikunto (dalam Mulyadin, 2010) mengartikan bahwa penelitian tindakan kelas merupakan suatu pencermatan terhadap kegiatan belajar berupa sebuah tindakan, yang sengaja dimunculkan dan terjadi dalam sebuah kelas secara bersama. Berikut dijabarkan kegiatan yang dilakukan pada setiap tahap penelitiannya, antara lain: (1) Perencanaan (2) Pelaksanaan tindakan, (3) Observasi/Evalualuasi, (4) Refleksi. Yang menjadi populasi dan sampel pada penelitian ini adalah mahasiswa Semester 3 Program Studi Pendidikan Matematika STKIP Bima.

\section{HASIL DAN PEMBAHASAN}

\section{Hasil Penelitian}

\section{Siklus I}

a) Perencanaan

Dalam kesempatan ini peneliti menyusun Rencana Pembelajaran Semester (RPS) berdasarkan pendekatan saintifik (Metode 5M) dengan tiga tahapan yaitu mengamati, menanya, menalar, mencoba dan pembelajaran kolaboratif. Pada rancangan kegiatan peneliti akan mengoptimalkan aktivitas mahasiswa di kelas sehingga dapat meningkatkan aktivitas sehingga diharapkan akan berdampak pada hasil belajar.

Penelitian ini dilaksanakan selama 8 kali pertemuan, sebelum melaksanakan penelitian dilakukan perencanaan tindakan terlebih dahulu dalam mempersiapkan segala sesuatu yang berkaitan dengan kegiatan pembelajaran saintifik (Metode 5M), diantaranya:

1) Menyusun perangkat pembelajaran

2) Membuat lembar kerja mahasiswa

3) Menyusun tes evaluasi

4) Menyusun pedoman penskoran dan jawaban tes evaluasi

b) Tindakan / Proses Pembelajaran

1) Pertemuan pertama

Pertemuan pertama hari Selasa 11/09/2018 ruangan 37 peneliti masuk kelas untuk mengajar mahasiswa semester IIIA. Sebelum memulai pelajaran peneliti meminta mahasiswa untuk mempersiapkan diri menerima materi yang akan diajarkan Sitem bilangan bulat. Selanjutnya peneliti menginformasikan bahwa kegiatan pembelajaran hari ini menggunakan 
pendekatan Saintifik (Metode 5M). Peneliti memulai pelajaran dengan melalukan apersepsi yaitu menyegarkan kembali ingatan mahasiswa tentang sistem bilangan bulat.

Karena mahasiswa masih ingat maka peneliti menjelaskan materi tersebut secara singkat untuk memastikan bahwa mereka masih ingat dan paham, lalu peneliti memberikan stimulus kepada mahasiswa dengan cara menyuruh mahasisawa mengamati gambar berbagai jenis dedaunan, dengan harapan muncul pertanyaan dari mahasiswa. Dan disini seorang mahasiswa bertanya "kenapa gambar daunnya berbeda-beda pak? Kenapa tidak hanya satu jenis daun saja?". Setelah ada pertanyaan peneliti menjelaskan alasan kenapa menampilkan gambar yang berbeda, dengan tujuan ingin melihat apakah dengan tampilan gambar tersesebut mahasiswa menyadarinya atau tidak. Setelah adanya penjelasan tersebut mahsiswa diminta mencoba mencari atau bereksperimen mencari ide lain baik itu berupa gambar, vidio, dan lainlain untuk melihat pemahaman mereka terntang materi yang dipelajari. Kemudian langkah berikutnya siswa mengolah informasi yang sudah didapatkan dari percobaan yang dilakukan tersebut, menghubungkan fenomena ysng terkait dalam rangka menemukan suatu pola, dan menyumpulkan. Dan langkah terakhir yaitu mahsiswa diminta mengkomunikasikan atau menyampaikan hasil pengamatan, kesimpulan berdasarkan hasil analisis secara lisan dan tulisan. Peneliti memperhatikan kesimpulan dari hasil analisis yang disampaikan oleh mahasiswa untuk meberikan penjelasan yang benar jika ada kekeliruan dari mahasiswa tersebut.

2) Pertemua kedua

Pertemuan pertama hari Selasa 18/09/2018 ruangan 37 peneliti masuk kelas untuk mengajar mahasiswa semester IIIA. Sebelum memulai pelajaran peneliti meminta mahasiswa untuk mempersiapkan diri menerima materi yang akan diajarkan. Selanjutnya peneliti menginformasikan bahwa kegiatan pembelajaran hari ini menggunakan pendekatan Saintifik (Metode 5M). Peneliti memulai pelajaran dengan melalukan apersepsi yaitu menyegarkan kembali ingatan mahasiswa tentang kelanjutan dari materi sistem bilangan bulat. Kemudian mahasiswa diabsensi dan pada pertemuan ini ada 3 orang mahasisawa yang tidak hadir.

Karena mahasiswa masih ingat maka peneliti menjelaskan materi tersebut secara singkat untuk memastikan bahwa mereka masih ingat dan paham, lalu peneliti memberikan stimulus kepada mahasiswa dengan cara menyuruh mahasisawa mengamati gambar berbagai jenis tanaman hias, dengan harapan muncul pertanyaan dari mahasiswa. Setelah ada 
pertanyaan peneliti menjelaskan alasan kenapa menampilkan gambar yang berbeda, dengan tujuan ingin melihat apakah dengan tampilan gambar tersesebut mahasiswa menyadarinya atau tidak. Setelah adanya penjelasan tersebut mahsiswa diminta mencoba mencari atau bereksperimen mencari ide lain baik itu berupa gambar, vidio, dan lain-lain untuk melihat pemahaman mereka terntang materi yang dipelajari. Kemudian langkah berikutnya siswa mengolah informasi yang sudah didapatkan dari percobaan yang dilakukan tersebut, menghubungkan fenomena ysng terkait dalam rangka menemukan suatu pola, dan menyumpulkan. Dan langkah terakhir yaitu mahsiswa diminta mengkomunikasikan atau menyampaikan hasil pengamatan, kesimpulan berdasarkan hasil analisis secara lisan dan tulisan.

Peneliti memperhatikan kesimpulan dari hasil analisis yang disampaikan oleh mahasiswa untuk meberikan penjelasan yang benar jika ada kekeliruan dari mahasiswa tersebut.

\section{3) Pertemuan ketiga}

Pertemuan ketiga hari Kamis tanggal 25/09/2018 pukul 07.30 WIT ruangan 37 peneliti masuk kelas untuk mengajar mahasiswa semester III A. Sebelum memulai pelajaran peneliti meminta mahasiswa untuk membersihkan papan, merapikan kursi lalu mengecek kehadiran, hari ini 27 mahasiswa hadir.

Melanjutkan pembahasan pada pertemuan yang lalu, peneliti membagikan lembar jawaban dan meminta mahasiswa berpasangan agar mahasiswa bersosialisasi dengan temannya yang lain. Peneliti memberikan waktu 5 menit untuk berdiskusi sesuai dengan gambar yang diperlihatkan dipapan tulis, kemudian peneliti menunjuk salah satu mahasiswa untuk mengelompokkan gambar-gambar sesuai dengan jenisnya., berdasarkan hasil presentasi dan respon mahasiswa lainnya untuk materi telah dikuasai maka peneliti melanjutkan pada materi sistem bilangan bulat. Peneliti menjelaskan secara singkat materi tersebut, untuk menemukan Keterbagian dengan gambar yang ada. Setelah dijelaskan, yang peneliti lakukan yaitu dengan menunjuk mahasiswa secara acak dengan tujuan untuk mengecek pemahaman mahasiswa secara individu.

Materi sistem bilangan bulat dirasa telah cukup dipahami maka peneliti memberikan informasi kepada mahasiswa untuk menyiapkan diri untuk menerima materi berikutnya dengan cara membaca materi tentang KPK dan FPB. 
4) Pertemuan keempat

Pertemuan keempat hari kamis 02/10/2018 pukul 07.30 WIT ruangan 37 peneliti masuk kelas untuk mengajar mahasiswa semester III A. Sebelum memulai pelajaran peneliti meminta mahasiswa untuk membersihkan papan, merapikan kursi lalu mengecek kehadiran, hari ini 25mahasiswa yang hadir dan 2 mahasiswa sakit.

Hari ini sesuai rencana akan dilaksanakan tes akhir untuk siklus 1. Tes dilaksanakan selama 90 menit sebanyak 5 soal essay, tes akhir berlangsung dengan tertib dan bisa dipastikan mahasiswa mengerjakan tes secara individu karena butiran tes yang dibuat beragam.

\section{Data Hasil Belajar}

Setelah dilakukan proses pembelajaran dengan pendekatan saintifik (metode 5M) maka peneliti melakukan tes evaluasi. Berdasarkan hasil tes evaluasi pada siklus I diperoleh data hasil belajar sebagai berikut.

Tabel 1. Data Hasil Belajar Siklus I

\begin{tabular}{ll}
\hline Pernyataan & Keterangan \\
\hline Peserta tes & 26 \\
Peserta lulus tes & 15 \\
Peserta tidak lulus tes & 11 \\
Persentase siswa $\geq 70$ & 57,69 \\
Persentasse siswa $\leq 70$ & 42,31 \\
\hline
\end{tabular}

Tabel 1. di atas memperlihatkan data bahwa:

1. Jumlah mahasiswa yang mendapat nilai $\geq 70$ sebanyak 15 mahasiswa

2. Jumlah mahasiswa yang mendapat nilai $\leq 70$ sebanyak 11 mahasiswa

3. Mahasiswa yang memiliki ketuntasan belajar sebanyak 15 dari 26 mahasiswa yang mengikuti tes atau 57,69\% sedangkan yang belum tuntas sebanyak 12 dari 25 mahasiswa yang mengikuti tes atau $42,31 \%$. 
c) Refleksi

Refleksi merupakan bagian yang penting dalam setiap langkah proses penelitian tindakan untuk mengatasi permasalahn. Dengan merivisi perencanaan sebelumnya sesuai apa yang ditemukan di lapangan. Dalam penelitian ini kegiatan refleksi difokuskan permasalahan pada kegiatan pembelajaran terkait dengan aktivitas mahasiswa, permasalahan tersebut antara lain:

1). Proses pembentukan kelompok cenderung membutuhkan waktu lama sehingga waktu untuk berdiskusi menjadi berkurang

2). Kurang aktifnya mahasiswa untuk bertanya dan memberi tanggapan terhadap permasalahan yang sedang dibahas

3). Masih ada beberapa mahasiswa yang tidak berani dan malu untuk mempresentasikan hasil diskusi kelompoknya

4). Saat diskusi didominasi oleh mahasiswa yang pandai

5). Hasil belajar masih belum mencapai kriteria ketuntasan maksimal (KKM) yaitu 75\%

Secara garis besar, pelaksanaan pada siklus I kurang berhasil. Hal ini dapat dilihat dari data yang telah diperoleh dan hasil nilai tes siklus I yang menunjukkan persentase ketuntasan belajar secara klasikal adalah 57,69\% kurang dari $75 \%$ yang merupakan tolak ukur keberhasilan. Dengan demikian kegiatan pada siklus I perlu diulang agar hasil belajar mahasiswa dalam menyelesaikan masalah dengan menggunakan pendekatan saintifik (metode 5M) dapat lebih meningkat.

\section{Siklus II}

a) Perencanaan

Rencana tindakan pada siklus II ini dilakukan dengan memperhatikan hasil refleksi I.

1. Mengidentifikasi dan merumuskan masalah berdasarkan refleksi pada siklus I

2. Menyususn perangkat pembelajaran

3. Menyusun tes evaluasi

b) Proses Pembelajaran

5) Pertemuan kelima

Pertemuan kelima hari Kamis tanggal 09/10/2018pukul 07.30 WIT ruangan 37 peneliti masuk kelas untuk mengajar mahasiswa semester III A. Sebelum memulai pelajaran peneliti meminta mahasiswa untuk membersihkan papan, merapikan kursi lalu mengecek kehadiran, 
hari ini 23 mahasiswa yang hadir, 3 ijin. Pertemuan kelima ini merupakan pertemuan pertama pada siklus 2, berdasarkan hasil tes pada siklus 1 diperoleh bahwa lebih dari $50 \%$ mahasiswa memperoleh nilai dibawah 70. Pada pertemuan ini peneliti membagikan lembar jawaban tes yang telah diberi nilai dengan tujuan agar mahasiswa dapat mengetahui tingkat penguasaan materi mereka. Setelah membagikan lembar jawaban peneliti meminta mahasiswa untuk mengungkapkan soal-soal dan materi apa yang belum dipahami atau dianggap sulit. Dari jawaban mahasiswa disimpulkan bahwa mereka bingung ketika contoh soal yang diberikan berbeda dengan soal latihan atau soal tes yang diberikan dan ada beberapa yang masih belum memahami materi sistem bilangan bulat. Berdasarkan temuan tersebut, maka peneliti membahas kembali latihan soal-soal terkait materi Sistem bilangan bulat untuk beberapa soal peneliti menunjuk salah seorang mahasiswa dengan inisial $\mathbf{M}$ untuk menjelaskan kepada temannya yang lain, $\mathrm{M}$ adalah salah satu mahasiswa yang nilai tesnya lulus. Pada pertemuan ini hanya diisi dengan pembahasan soal latihan, sebelum menutup pelajaran peneliti menginformasikan untuk pertemuan selanjutnya akan dilanjutkan dengan Notasi dan prinsip keterbagian.

6) Pertemuan keenam

Pertemuan keenam hari Kamis tanggal 16/10/2018 pukul 07.30 WIT ruangan 37 peneliti masuk kelas untuk mengajar mahasiswa semester III A. Sebelum memulai pelajaran peneliti meminta mahasiswa untuk membersihkan papan, merapikan kursi lalu mengecek kehadiran, hari ini semua mahasiswa hadir.

Sesuai dengan informasi yang peneliti sampaikan pada minggu lalu bahwa hari ini akan membahas sub Notasi dan prinsip keterbagian. selanjutnya peneliti mulai membahas segmen garis. Pada bagian ini akan dibicarakan koordinat sebuah titik yang membagi definisi habis bagi dan teorema habis bagi, setelah peneliti menjelaskan materi dan membahas contohcontoh soal selanjutnya adalah memberikan latihan 2 nomor secara individu selama 10 menit. Setelah membahas latihan bersama-sama dan mahasiswa dianggap telah memahami maka peneliti memberikan lagi 3 soal yang dikerjakan secara individu. Tiga soal yang peneliti beri dikerjakan sampai akhir jam perkuliahan, oleh karena itu lembar jawaban dikumpulkan dan akan dilanjutkan pada pertemuan selanjutnya. Sebelum mengakhiri tatap muka, peneliti meminta mahasiswa untuk tetap melanjutkan diskusi di rumah. 


\section{7) Pertemuan ketujuh}

Pertemuan keenam hari Kamis tanggal 23/10/2018 pukul 07.30 WIT ruangan 37 peneliti masuk kelas untuk mengajar mahasiswa semester IIIA. Sebelum memulai pelajaran peneliti meminta mahasiswa untuk membersihkan papan, merapikan kursi lalu mengecek kehadiran, hari ini semua mahasiswa hadir.

Melanjutkan pembahasan pada pertemuan yang lalu, peneliti meminta mahasiswa untuk berdiskusi, ditetapkan selama 15 menit, setiap nomor soal diberi waktu masing-masing 5 menit, selama mahasiswa berdiskusi peneliti memantau sambil berkeliling dan menginformasikan akan diadakan tes evaluasi pada pertemuan minggu depan maka diharapkan mahasiswa belajar dengan sungguh-sungguh. Setelah 15 menit maka peneliti memanggil secara acak salah satu mahasiswa yaitu W untuk mempresentasikan hasil diskusinya tetapi $\mathrm{W}$ tidak mau maju karena malu, takut dan belum paham. Untuk memotivasinya peneliti mengatakan bahwa apapun hasil diskusinya akan kita hargai dan akan dibahas bersama-sama tidak ada hukuman dalam hal ini, setelah mendengar penjelasan peneliti dan dorongan dari teman-temannya maka yang bersangkutan bersedia tampil, tetapi untuk soal yang dibahas oleh $\mathrm{W}$ ada sedikit kesalahan dalam menghitung sehingga peneliti meminta tanggapan dari mahasiswa lain dan diperbaiki. Soal no.2 pun dibahas dengan cara menunjuk salah satu siswa, tetapi karena antusiasnya mahasiswa untuk tampil ada beberapa yang langsung maju sehingga peneliti menunjuk salah satunya yaitu AS dan membahas soal, untuk nomor ini tidak ada masalah maka dilanjutkan ke soal nomor 3.

Setelah membahas soal yang diberikan, peneliti menanyakan pemahaman mahasiswa dan mereka mengatakan sudah paham dan siap untuk tes evaluasi minggu depan sehingga peneliti menutup perkuliahan dan mengingatkan agar selalu belajar di rumah.

\section{8) Pertemuan kedelapan}

Pertemuan keempat hari Kamis tanggal 30/10/2018 pukul 07.30 WIT ruangan 38 peneliti masuk kelas untuk mengajar mahasiswa semester III A. Sebelum memulai pelajaran peneliti meminta mahasiswa untuk membersihkan papan, merapikan kursi lalu mengecek kehadiran, hari ini semua mahasiswa hadir.

Hari ini sesuai rencana akan dilaksanakan tes akhir untuk siklus 2. Tes dilaksanakan selama 90 menit sebanyak 5 soalyang semuanya soal essay, tes akhir berlangsung dengan 
tertib dan bisa dipastikan mahasiswa mengerjakan tes secara individu karena butiran tes yang dibuat beragam.

\section{Data Hasil Belajar}

Berdasarkan hasil tes evaluasi pada siklus II diperoleh data hasil belajar sebagai berikut.

Tabel 2. Data Hasil Belajar Siklus II

\begin{tabular}{ll}
\hline Pernyataan & Keterangan \\
\hline Peserta tes & 26 \\
Peserta lulus tes & 26 \\
Peserta tidak lulus tes & 0 \\
Persentase siswa $\geq 70$ & 0 \\
Persentasse siswa $>70$ & 100 \\
\hline
\end{tabular}

Tabel 2. di atas memperlihatkan data bahwa:

1. Jumlah mahasiswa yang mendapat nilai $\geq 70$ sebanyak 26 mahasiswa

2. Jumlah mahasiswa yang mendapat nilai $\leq 70$ sebanyak 0 mahasiswa

3. Mahasiswa yang memiliki ketuntasan belajar sebanyak 26 dari 26 mahasiswa yang mengikuti tes atau $100 \%$.

\section{PEMBAHASAN}

Pelaksanaan tindakan terhadap hasil belajar mahasiswa pada siklus I dan II menunjukkan bahwa penerapan pendekatan saintifik (metode 5M) mampu meningkatkan hasil belajar mahasiswa pada mata kuliah Teori Bilangan untuk semester IIIA STKIP Bima. Peningkatan hasil belajar tersebut dapat di lihat pada tabel berikut:

Tabel 3. Data Hasil Belajar Siklus I dan II

\begin{tabular}{ccc}
\hline Pernyataan & Keterangan & keterangan \\
\hline Peserta tes & 26 & 26 \\
Peserta lulus tes & 15 & 26 \\
Peserta tidak lulus tes & 11 & 0 \\
Persentase siswa $\geq 70$ & 57,69 & 100 \\
Persentasse siswa $\leq 70$ & 42,31 & 0 \\
\hline
\end{tabular}


Tabel di atas menunjukan hasil belajar mahasiswa selama proses pembelajaran pada siklus I mahasiswa yang memiliki ketuntasan belajar sebanyak 15 dari 26 mahasiswa yang mengikuti tes atau 57,69\% sedangkan yang belum tuntas sebanyak 11 dari 26 mahasiswa yang mengikuti tes atau $42,31 \%$, sedangkan pada siklus II mahasiswa yang memiliki ketuntasan belajar sebanyak 26 dari 26 mahasiswa yang mengikuti tes atau tes atau 100\% sedangkan yang belum tuntas sebanyak 0 mahasiswa, maka terjadi peningkatan hasil belajar pada siklus I ke siklus II.

\section{KESIMPULAN}

Berdasarkan hasil penelitian maka dapat disimpulkan bahwa: Pendekatan Saintifik mampu meningkatkan hasil belajar mahasiswa semester III A melalui tahapan yaitu mengamati, menanya, menyajikan, menalar, dan mencoba. Ketuntasan belajar pada siklus I sebesar 57,69\% sedangkan pada siklus II sebesar $100 \%$.

\section{REKOMENDASI}

Beberapa saran ditujukan untuk berbagai pihak, antara lain:

1. Untuk dosen, diharapkan selalu melaksanakan kegiatan pembelajaran dengan berbagai metode inovatif agar kegiatan pembelajaran di kelas tidak monoton, membosankan dan mampu memberi stimulus untuk meningkatkan kreatifitas mahasiswa sehingga hasil belajarpun akan meningkat.

2. Untuk mahasiswa, diharapkan kepada seluruh mahasiswa agar memotivasi diri sendiri untu belajar, membaca buku dan berbagai sumber lainnya sehingga mampu meningkatkan wawasan dan ilmu pengetahuan.

3. Untuk lembaga, diharapkan selalu mendukung aktivitas tri dharma perguruan tinggi yang dilakukan dosen sehingga dosen lebih semangat dan terpacu lagi untuk selalu berkarya.

\section{UCAPAN TERIMAKASIH}

Ucapan terimakasih ini penulis mengucapkan terimakasih kepada:

1. Dr. Amran Amir, M. Pd selaku ketua STKIP Bima

2. Rekan-rekan dosen-dosen program studi pendidikan matematika 


\section{REFERENSI}

Kemdikbud. (2013). Materi pelatihan guru implementasi kurikulum 2013 SMA. Jakarta: Dirjen Dikdasmen Kemdikbud

Kong, Chow Ming. (2003). Mastery of Mathematical Induktion among Junior College Students. The Mathematics Educator 2003, vol. 7 No.2, 37-54.

Mulyadin, E. (2010). Penerapan Metode Pembelajaran Tipe Group Investigation (GI) Untuk Meningkatkan Pemahaman Materi Operasi Aljabar Pada Siswa Kelas VIII SMP Muhammadiyah 06 Malang (Doctoral dissertation, University of Muhammadiyah Malang).

Mulyadin, E. (2013). Efektivitas Kebijakan Pendidikan Budi Pekerti Pada Komunitas Homeschooling Sekolah Dolan Kota Malang (Doctoral dissertation, University of Muhammadiyah Malang).

Mulyadin, E., \& Riyadi, K. (2018). Implementasi Kurikulum 2013 (K-13) dengan Pendekatan Saintifik (Metode 5M) Terhadap Siswa pada Mata Pelajaran Matematika di SMA/MA Negeri Kec. Sape. Jurnal Edukasi Matematika dan Sains, 6(2), 103-112.

Sriaryaningsyih, S. (2019). Analisis Pembelajaran Matematika pada Materi Perpangkatan dengan Model Pembelajaran Multiple Intelligences. Jurnal Edukasi Matematika dan Sains, 6(1), 1-18.

Taufik. (2014). Diagnosis Kesulitan Mahasiswa di universitas swadaya gunung jati dalam pembuktian menggunakan induksi matematika dan upaya mengatasi menggunakan Scaffolding. Tesis Tidak Diterbitkan. Malang: PPS UM.

Wibawa, B. (2003). Penelitian Tindakan Kelas. Jakarta: Depdiknas Dirjend Dikdasmen Direktorat Tenaga Kependidikan 